\section{Ukrainian Journal \\ of Educational Studies and Information Technology}

ISSN: 2521-1234 online

Ukr. J. of Educ. Stud. and Inf. Technol.

$8(4), 38-51$

doi: 10.32919/uesit.2020.04.04

Vol. 8, Issue 4, 2020

УДК 371.33 .336

\section{Значимість інтерактивних та практико- зорієнтованих ігор у процесі викладання фінансової грамотності в закладах освіти}

\author{
Ребуха Лілія Зіновіївна, Кізима Тетяна Олексіївна, \\ Письменний Віталій Валерійович
}

\begin{abstract}
Анотація
В статті розглянуто можливості використання ігрових технологій навчання фінансовій грамотності у закладах загальної середньої освіти. Акцентовано увагу на методиці викладання фінансової грамотності, яка орієнтована на інноваційний спосіб організації навчання та оптимальну реалізацію завдань інтерактивного та практико-зорієнтованого освітнього процесу. Проаналізовано низку науково-педагогічних та просвітницьких заходів з фінансової грамотності, проведених у Західноукраїнському національному університеті спільно з педагогами закладів загальної середньої, професійної та вищої освіти щодо тенденцій та перспектив використання ігрових технологій в освітньому процесі. Акцентовано увагу на важливості впровадження в закладах освіти ігрового моделювання, що сприяє переорієнтації набутих знань і вмінь 3 фінансової грамотності із зовнішньої сфери у внутрішньо-особистісну із наступним їх дієвим вивільненням під час практичного застосування. Наведена коротка характеристика проведення авторських настільних інтерактивно-фінансових ігор «Мій перший мільйон», «Мій бюджет», «Малі підприємці», «Оплата в магазині», «Банківська картка», «Банкомат», «Телефонне шахрайство» та здійснена їх апробація на курсах підвищення фінансової грамотності для дітей учасників АТО. Після успішного проходження курсів проведено анкетне опитування щодо оцінки рівня знань кожного з основ фінансової грамотності. Відстежено, що в 63,79\% школярів переважає високий і достатній рівень отриманих знань $з$ фінансової грамотності. Недостатній рівень знань з питань умілого управління особистими коштами, набуття навичок заощадження 3 найменшими втратами та найбільшими вигодами, убезпечення від фінансових шахраїв виявлено у 24,13\% респондентів, що вимагає подальшої послідовної роботи викладачів із школярами у напрямі формування фінансових компетентностей. Проведене дослідження довело важливість використання ігрового компоненту навчання як суттєвого доповнення до традиційних методів викладання фінансової грамотності у закладах освіти та курсах з формування курсах з формування фінансових компетентностей у школярів.
\end{abstract}

Ключові слова: заклад освіти; ігрові технології навчання; фінансова грамотність; настільні фінансові ігри.
Submitted:

14 September 2020

Accepted:

05 December 2020

Published online:

30 December 2020

(C) L. Rebukha

(C) T. Kizyma

(C) V. Pysmennyi

This work is licensed under a "CC BY 4.0" license. 


\title{
The importance of interactive and practically oriented games in the process of financial literacy teaching at educational institutions
}

Ukr. J. of Educ. Stud. and Inf. Technol. 2020, 8(4)

\author{
Liliia Rebukha, Tetyana Kizyma, Vitalii Pysmennyi
}

\begin{abstract}
This article considers the possibilities of game technologies using for financial literacy teaching in the institutions of general secondary education. The attention is emphasized on the methodology of financial literacy teaching, which is focused on an innovative way of training and optimal implementation of tasks of interactive and practically oriented educational process. It is analyzed a number of scientific pedagogical and educational activities on financial literacy, which were conducted at the Western Ukrainian National University together with teachers of general secondary, vocational and higher education institutions about the trends and prospects of using game technologies in the educational process. The attention emphasizes on the importance of game modeling introducing in the educational institutions, which contributes to the reorientation of acquired knowledge and skills of financial literacy from the external sphere to internal, followed by their effective release during practical application. In this article there is a brief description of the author's board interactive financial games "My first million", "My budget", "Small entrepreneurs", "Payment in the store", "Bank card", "ATM", "Telephone fraud" and their testing at the courses of financial literacy for anti-terrorist operation participants' children. A questionnaire survey among schoolchildren was conducted after a successful completion of the courses, to assess the level of knowledge of financial literacy basics. It was observed that $63.79 \%$ of schoolchildren have the high and sufficient level of knowledge of financial literacy. The insufficient level of knowledge on the issues of skillful management of personal funds, acquisition of savings skills with the least losses and greatest benefits, protection against financial fraud was found in $24.13 \%$ of respondents, which requires the further consistent work of teachers with schoolchildren in the formation of financial competencies. This study proved the importance of using of teaching game component as a significant addition to the traditional methods of financial literacy teaching in educational institutions and courses for the formation of financial competencies in schoolchildren.

Keywords: educational institution; game learning technologies; financial literacy; board financial games.
\end{abstract}

\section{ВСТУП}

\section{Постановка проблеми}

Викладання фінансової грамотності в освітніх закладах України стало важливим кроком на шляху до гармонізації системи загальної середньої освіти в глобальному процесі формування фінансово освіченого покоління. Утім досвід засвідчує, що в Україні все ще актуальною продовжує залишатися проблема широкого застосування інтерактивних та практико-зорієнтованих методик викладання фінансової грамотності педагогами закладів загальної середньої освіти, насамперед у контексті активізації використання ігрових технологій навчання фінансовій грамотності. 


\section{Аналіз останніх досліджень і публікацій}

Використанню ігрових технологій в освіті присвячені дослідження Т. Гранчак (2019), І. Мельничук (2011), В. Ковальчука (2017), Т. Черкашиної та А. Аббасової (2014) та ін. Питання гейміфікації, як однієї з інноваційних форм навчального процесу, висвітлені в працях О. Бабире (2017), Н. Кравець (2017), Т. Лященко, В. Гришуніної та В. Пічкур (2018), А. Маркеєвої (2017) та ін. Формування ціннісних орієнтацій студентів в умовах інтерактивної взаємодії вивчали І. Мельничук, Л. Ребуха та С. Мельничук (2008). Особливості використання дидактичних ігор у процесі навчання у закладах загальної середньої освіти розглядаються О. Зеленською (2016), М. Курик (2016), А. Шапієвою та П. Магомедовою (2015). Традиційне викладання, в якому домінує словесний підхід та спрямованість навчального матеріалу на запам'ятовування, науковцем A. Xhemajli (2016) замінено на практико-зорієнтований інтерактивний вид діяльності викладачу з його майбутньою перспективністю в освітньому процесі закладу освіти та дано його об'єктивну оцінку. Значимість інтерактивного підходу в ефективній освітній взаємодії та наданні допомоги всім учасникам групи під час вивчення іноземної мови досліджували M.Safa та S. Beheshti (2018). Інноваційні технології, що використовуються в сучасному освітньому процесі, відстежено у працях Р. Горбатюка та У. Дудки (2019), Л. Ребухи (2017), Т. Кізими, І. Круп’як і Н. Коломийчук (2020) та ін. Однак, зважаючи на те, що предмет «Фінансова грамотність» запроваджений у закладах загальної середньої освіти поки що як факультативний (проте Міністерство освіти і науки України планує зробити курс фінансової грамотності постійним шкільним предметом

(https://zak.depo.ua/ukr/zak/u-shkolakh-ukraini-mozhutzaprovaditi-urok-finansova-gramotnist-202004301154679), нині недостатньо вирішеними залишаються проблеми, пов’язані 3 інтерактивними та практико-зорієнтованими методиками викладання фінансової грамотності в освітніх закладах, які потребують наукового дослідження.

Метою статті $\epsilon$ обгрунтування ефективності використання інтерактивних та практико-зорієнтованих ігор у процесі викладання фінансової грамотності в освітніх закладах для підвищення пізнавального інтересу дітей і молоді до основних компонент фінансової грамотності та розвитку в них практичних вмінь і навичок ефективного управління особистими фінансами.

\section{ТЕОРЕТИЧНІ ОСНОВИ ДОСЛІДЖЕННЯ}

Еволюція сучасної середньої освіти відображається у суттєвих трансформаціях інтелектуальних здібностей школярів та їхньому діалектико-матеріалістичному світогляді, що сповна спрямовують особистість на розвиток творчості, індивідуальних моральних якостей та активного формування різноаспектних вмінь, навичок і досвіду
Ukr. J. of Educ. Stud. and Inf. Technol. 2020, 8(4) 
(Кремень, 2002). Впровадження навчального предмету «Фінансова грамотність» в сучасний освітній процес стало важливою складовою реформування системи загальної середньої освіти в Україні, оскільки йому передував процес створення національних стратегій та програм підвищення рівня фінансової грамотності населення у багатьох країнах світу (Смовженко \& Кузнєцова, 2013).

У цьому контексті науковці Н. Чечетова та Т. Чечетова-Терашвілі акцентують увагу на проблемі забезпечення фінансовою грамотністю населення України в цілому та виокремлюють низький рівень:

- фінансової грамотності та компетентності у сфері особистих фінансів;

- особистісних інвестиційних рішень щодо використання власних фінансів та усвідомлення ризиків, пов'язаних з такими рішеннями;

- грамотного управління особистими фінансами;

- реалізації національної політики щодо поліпшення фінансової грамотності учнів та молоді (Чечетова \& Т. Чечетова-Терашвілі, 2019).

Освітньому процесу в цілому відводиться вагома роль у розвитку фінансової грамотності підростаючого покоління, оскільки саме навчання покликане виконувати функції передавання та засвоєння фінансових знань, формування економічного мислення у дітей, що проявляється в умінні заощаджувати, витрачати та заробляти (Булавенко, 2018). Сьогодення показує, що школярі 3 певними труднощами засвоюють окремі питання окресленої проблеми, не завжди можуть чітко зрозуміти принципи управління особистими фінансами, а також успішно застосувати отримані знання і навички у практичному житті. А фінансова грамотність якраз і передбачає вміння особи розпоряджатися коштами 3 найменшими для себе втратами та найбільшими вигодами (Письменний \& Коженівський, 2020).

Науковці Т. Кізима, Л. Ребуха та ін. переконані, що формування основних компонент фінансової грамотності як вміння заощаджувати, вміння витрачати та вміння заробляти уможливлене за використання у закладах загальної середньої освіти ігрових технологій навчання (ізима та ін., 2020). Ігрові технології урізноманітнюють основні форми подання фінансової інформації учням 3 використанням мультимедійних засобів; активізують навчально-пізнавальну діяльність i самостійну роботу школярів; формують позитивну мотивацію до навчання та забезпечують їі диференціацію; розвивають в учнів фінансове мислення, логіку, уміння аналізувати й синтезувати інформацію, робити висновки; раціоналізують та насичують новаціями освітній процес; убезпечують високий результат педагогічної діяльності вчителя; забезпечують наочність навчального матеріалу; розвивають відповідну рефлексію (Горбатюк \& Дудка, 2019). Оволодіння економічними знаннями, як зазначає Б.Приходько, привабливе для школярів в ігровій формі й ефективно позначається на якості засвоєння (2014).
Ukr. J. of Educ. Stud. and Inf. Technol. 2020, 8(4) 
В сучасних умовах впровадження предмету «Фінансова грамотність» в освітній процес закладів загальної середньої освіти $є$ важливим фактором формування фінансово освіченого молодого покоління. Однак теоретичні знання, подані вчителем та здобуті учнями в процесі навчання, повною мірою засвоюються лише тоді, коли вони будуть апробовані на практиці. 3 метою удосконалення методики викладання фінансової грамотності у Західноукраїнському національному університеті уже кілька років поспіль на постійній основі організовуються і проводяться, спільно з педагогами західного регіону, низка цікавих і пізнавальних науково-педагогічних заходів (Кізима, Круп'як, \& Коломийчук, 2020), які розкривають тематику імплементації інтерактивних ігрових технологій навчання фінансовій грамотності в освітній процес.

Зокрема, у квітні 2017 року на базі університету відбувся Перший освітній форум «Упровадження курсу «Фінансова грамотність» в навчально-виховний процес у контексті змін сучасної освіти», мета якого полягала в обміні досвідом у сфері викладання фінансової грамотності, розширення рівня компетенції вчителів щодо управління особистими фінансами, формування відповідальної фінансової поведінки та прийняття обгрунтованих фінансових рішень. Учасники форуму мали змогу проаналізували досвід викладання фінансової грамотності у закладах загальної середньої та вищої освіти Тернопільської області, окреслити його науково-методичний супровід та взяти участь у тренінгу «Фінансові піраміди: вид шахрайства чи спосіб заробітку?».

Через рік у квітні 2018 року відбувся Другий регіональний освітній форум «Особливості впровадження курсу «Фінансова грамотність» у контексті модернізації освітнього процесу», який дав змогу його учасникам обговорити особливості впровадження методик грамотного формування сімейного бюджету, витрачання коштів, способів заощаджень у різних ситуаціях; представити досвід реалізації студентського стартапу «Від А до Я»; розглянули ігрові технології навчання, спрямовані на підвищення компетенції управління особистими фінансами.

Безперечно, фінансова грамотність визначає рівень життя громадян, сприяє подоланню бідності, зниженню економічних ризиків суб'єктів підприємництва та фізичних осіб (USAID, 2017). Такі реалії вимагають адекватної реакції освітянського простору на запити сьогодення. 3 цією метою на базі університету в листопаді 2018 року відбувся вернісажпрактикум для педагогів Тернопільської області «Проект «Фінансова грамотність» у контексті реформування освіти», в рамках якого учні загальноосвітніх шкіл та студенти коледжів Тернопілля взяли участь у квесті «Фінансове розслідування» та зіграли у фінансову гру «Alias: financial edition». 
Важливо зазначити, що удосконалення методики викладання фінансової грамотності допомагає учням зрозуміти сутність ключових фінансових понять, а також успішно застосовувати їх у процесі ухвалення рішень про доходи, витрати та заощадження. На третьому регіональному освітньому форумі з методики викладання фінансової грамотності, який відбувся у квітні 2019 року, були презентовані навчальні програми та просвітницькі проекти, спрямовані на підвищення компетенції дітей та молоді в процесі управління особистими фінансами та визначено перспективи підвищення кваліфікації вчителів щодо запровадження інноваційних освітніх форм навчання у сфері фінансової грамотності.

Важливою є популяризація фінансової грамотності серед молоді. Тому для учнів та вчителів Тернопільської, Львівської і Хмельницької областей був організований Другий Всеукраїнський вернісаж-практикум «Тиждень фінансової грамотності. Прев’ю» (жовтень 2019 р.), учасники якого обговорили можливості та перспективи підвищення кваліфікації освітян з фінансової грамотності. у рамках вернісажу-практикуму було презентовано настільні фінансові ігри для дітей: «Банківська картка», «Малі підприємці», «Мій перший мільйон», «Дитячий бюджет», «Вірю - не вірю», «Знайти фінансового шахрая» та «Квест в магазині» (Кізима, Круп'як, \& Коломийчук, 2020). Водночас для учнів студентами, котрі навчаються на магістерській освітньо-професійній програмі 015 «Фінансова грамотність», проведено низку заходів, спрямованих на отримання нових знань та практичних навичок у сфері фінансової грамотності.

Загалом для інтерактивних технологій навчання фінансовій грамотності характерне використання широкого спектра методів i прийомів організації освітньої діяльності, які дають змогу активізувати пізнавальний інтерес, краще сформувати компетенції і практичні навички дітей, оскільки передбачають проведення занять, в межах яких створено необхідні умови для максимального набуття фінансових знань та розкриття фінансових умінь і навичок учнів. Головна мета таких методик полягає у зануренні всіх суб’єктів освітнього процесу у професійну сферу діяльності, розкритті їхнього творчого потенціалу, формуванні навичок роботи у колективі, збільшенні зацікавленості учнів в оволодінні основами управління особистими фінансами та підвищенні рівня мотивації до навчання.

В сучасних реаліях незаперечною $є$ істина, що чим раніше діти пізнають основи особистих фінансів, тим більш фінансово успішними вони стануть у майбутньому. Саме з цією метою доктором економічних наук, доцентом кафедри фінансів імені С. І. Юрія Західноукраїнського національного університету В.Письменним та випускником магістратури цього університету С. Коженівським розроблено настільну фінансову гру «Мій перший мільйон» (рис. 1). Поряд із розвитком ерудиції та формуванням комунікативних навичок, настільна гра спрямовувалася на отримання знань у сфері особистих фінансів, отримання вмінь щодо розпорядження
Ukr. J. of Educ. Stud. and Inf. Technol. 2020, 8(4) 
грошима, планування особистого бюджету, заощадження та убезпечення від фінансових шахраїв тощо.

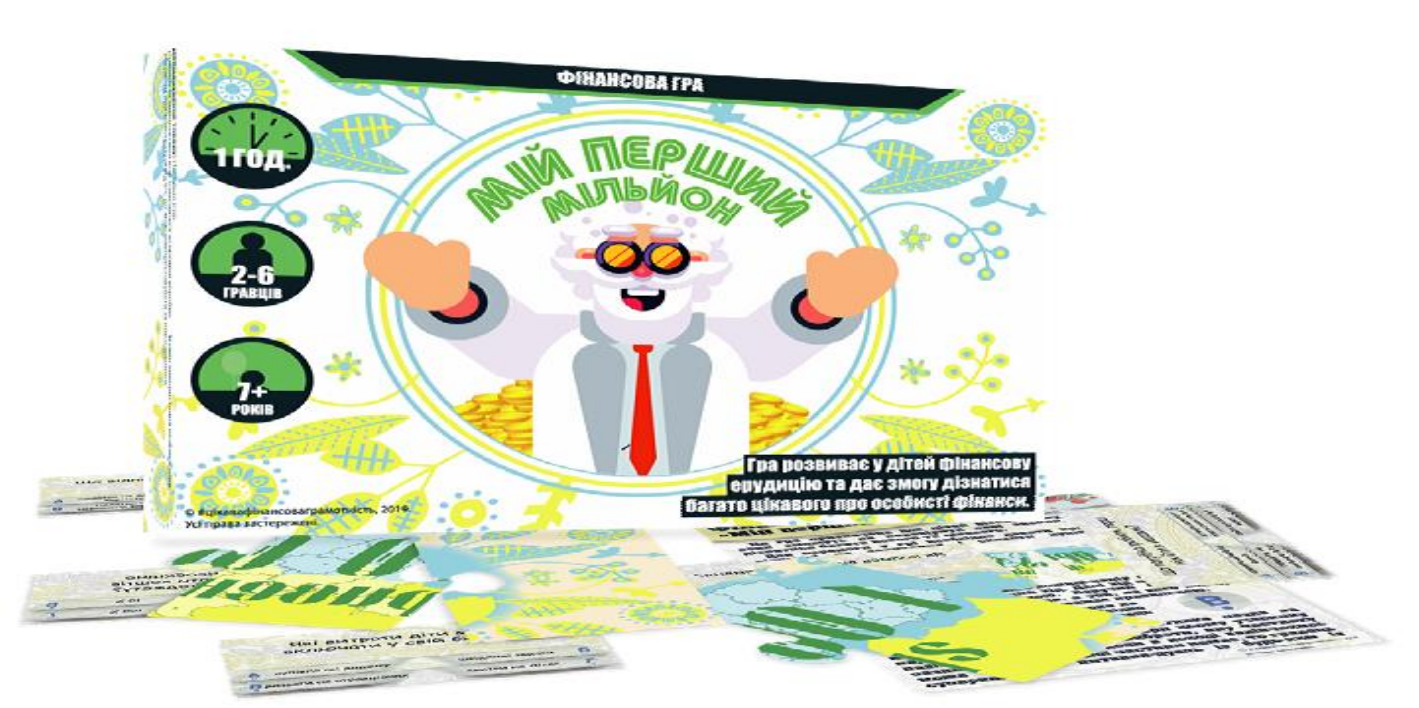

Рис. 1. Настільна фінансова гра «Мій перший мільйон»

Доволі часто діти не помічають, куди діваються наші гроші. Здається, що нічого особливого за місяць не купили, а грошей уже немає. Зрозуміти, на які цілі витрачено власні кошти, допоможе планування особистого бюджету та його аналіз. Настільна інтерактивна фінансова гра «Мій бюджет» (рис. 2) (автори: д.е.н., доцент В. Письменний і С. Коженівський) розроблена для того, щоб в ігровій формі показати дітям, наскільки просто та необхідно планувати особистий бюджет. Головна мета гри полягає у розвитку тактичного і логічного мислення дитини, іiі реакції та уважності, а також виробляє уміння реального оцінювання власної фінансової ситуації.

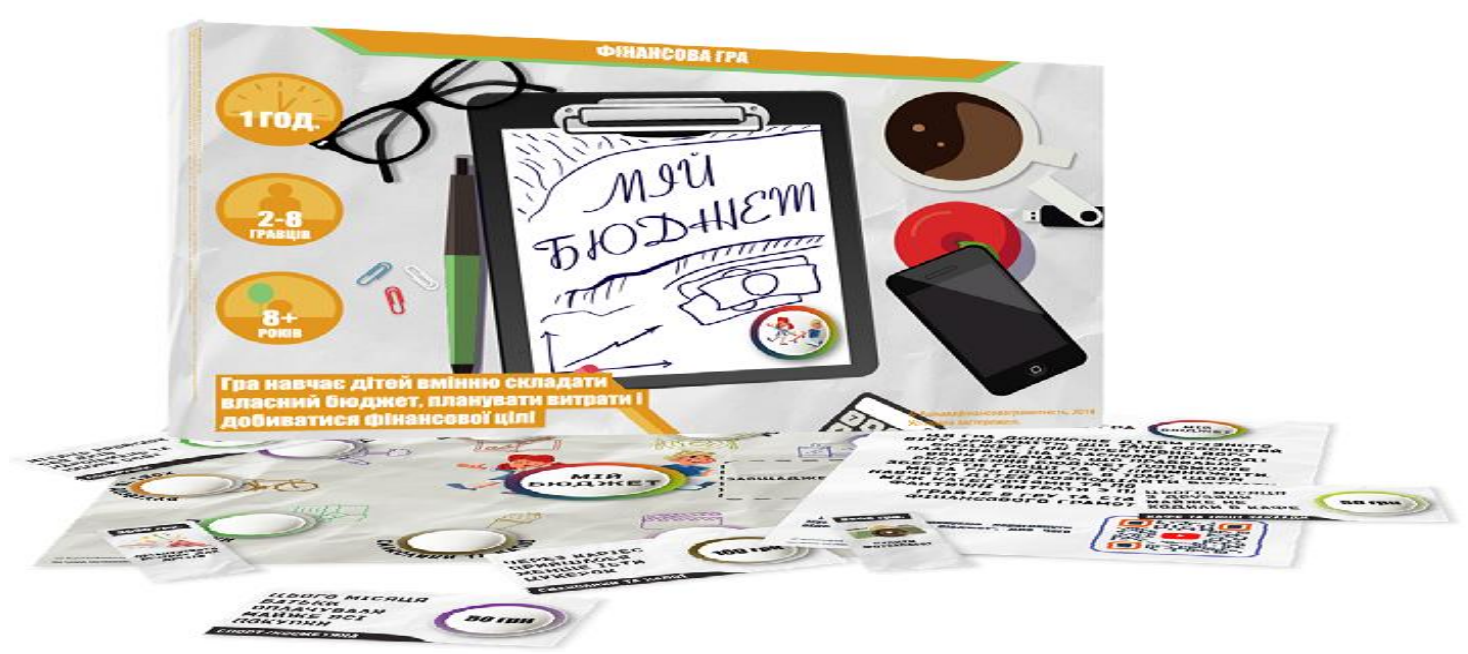

Рис. 2. Настільна фінансова гра «Мій бюджет» 
В сучасних умовах кожна дитина в той чи інший період часу задумується про відкриття власної справи (пекарні, салону краси, автомайстерні тощо). Настільна фінансова гра «Малі підприємці» (рис. 3) (автори: д.е.н., доцент В. Письменний і С. Коженівський) сприяє кращому зрозумінню підприємницької діяльності й дізнанню багато цікавого про прибуток, витрати, податки, банкрутство тощо.

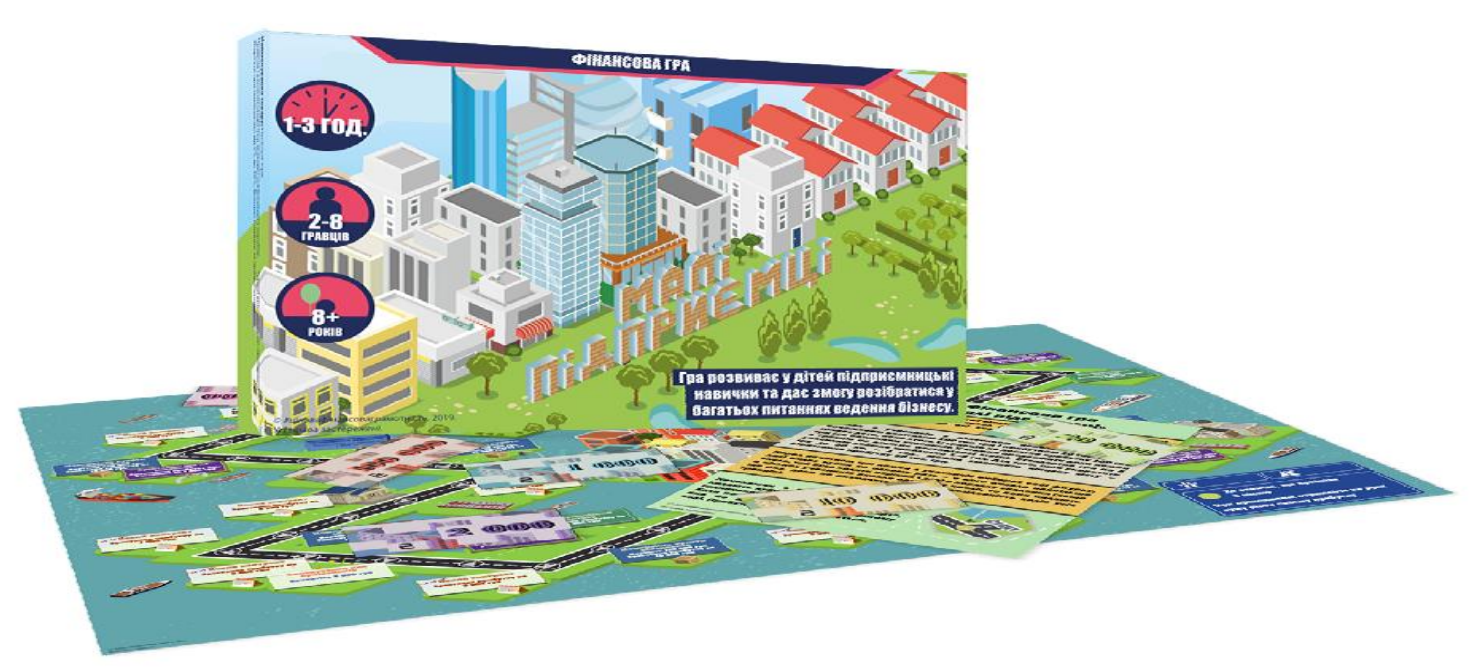

Рис. 3. Настільна фінансова гра «Малі підприсмці»

Майже всі сучасні діти знають як користуватися банківською карткою: знімати гроші з банкомата, поповнювати рахунок у терміналі, сплачувати за товари в супермаркеті або інтернет-магазині. Втім, чи вміють вони робити це безпечно? Адже на банківській картці може зберігатися значна сума грошей, яку втратити легко, не користуючись простими правилами протидії фінансовому шахрайству. Серія ігор «Оплата в магазині», «Банківська картка», «Банкомат», «Телефонне шахрайство» (автори: д.е.н., доцент В. Письменний і С. Коженівський), спрямована на опанування дітьми навичок безпечного користування банківською карткою та дізнання про лайфхаки, які можна щодня використовувати у повсякденному житті.

Організація, процедура та методика проведення зазначених ігор є авторськими розробками д.е.н., доцента В.Письменного і здобувача вищої освіти другого (магістерського) рівня С. Коженівського.

Усі запропоновані ігри пройшли успішну апробацію у 2019 році на курсах 3 фінансової грамотності для дітей (10-13р.) учасників АТО на запрошення університету. На завершення курсів нами було проведено розгорнуте дослідження із статистичними даними. Всі залучені до опитування респонденти (58 осіб) дали згоду приймати участь в дослідженні. Водночас нами одержано від них дозвіл на оприлюднення отриманих результатів 3 науковою та дослідницькою метою. Дослідження проводилися у жовтні 2019 року.
Ukr. J. of Educ. Stud. and Inf. Technol. 2020, 8(4) 
Для підтвердження ефективності використання ігор для формування навичок 3 фінансової грамотності нами було проведено анкетне опитування серед школярів. Анкета містила п'ять питань:

1. Оцініть особистий рівень знань з фінансової грамотності від 0 до 100 балів (дуже низький рівень - 0-39 балів; низький рівень - 40-59 балів; середній рівень - 60-74 бали; достатній рівень - 75-89 балів; високий рівень - 90-100 балів).

2. Дайте оцінку власного рівня знань 3 фінансової грамотності, що відноситься до вміння розпоряджатися власними коштами, заощаджувати ïx 3 найменшими втратами та найбільшими вигодами, навичками убезпечення від фінансових шахраїв від 0 до 100 балів (дуже низький рівень - 0-39 балів; низький рівень - 40-59 балів; середній рівень - 60-74 бали; достатній рівень - 75-89 балів; високий рівень - 90-100 балів).

3. Чи відчуваєте Ви потребу в подальшому підвищенні рівня знань 3 фінансової грамотності? (Так. Ні.).

4. Чи сприяють Вам знання з фінансової грамотності відчувати себе більш комфортно серед однокласників, котрі їх професійно не отримували? (Так. Ні.).

5. Якщо Ви відповіли «Так» на питання №4, то чи здійснюєте Ви щоденне ефективне управління особистими фінансами? (Так. Нi).

На перше запитання жодна дитина не оцінюе свій рівень знань 3 фінансової грамотності на менше ніж 60 балів за 100 бальною шкалою. Високий рівень засвідчили 12 (20,69\%) учнів; достатній - 25 (43,10\%); 21 (36,21\%) особа вважає, що має середній рівень. Отож, у 37 (63,79\%) школярів переважає високий $\mathrm{i}$ достатній рівень отриманих знань з фінансової грамотності.

Проте відповіді на друге запитання розподілилися так: власним високим рівнем знань з фінансової грамотності, що відноситься до вміння розпоряджатися власними коштами, заощаджувати ї 3 найменшими втратами та найбільшими вигодами, навичками убезпечення від фінансових шахраїв володіють 23 (39,66\%) учні (3 них в 7 осіб $(12,07 \%)$ високий рівень знань та в $16(27,59 \%)$ - достатній рівень), середні знання у цьому спрямуванні має 21 (36,21\%) школяр, проте у $14(24,13 \%)$ - рівень знань 3 фінансової грамотності ще не $\epsilon$ достатнім й таким, щоб уміло управляти особистими фінансами.

Розподіл відповідей на перше i друге запитання анкети показано на рис. 4.

На третє запитання анкети розподіл думок учнів, котрі пройшли успішну апробацію на курсах $з$ фінансової грамотності був наступним: $10(17,24 \%)$ осіб вважають, що їм ще потрібно підвищувати свій рівень знань $з$ фінансової грамотності. Однак більша частина (48 (82,76\%) учнів) зазначили, що задоволені отриманими знаннями і на даний час потреби у більшому набутті знань з фінансової грамотності немає.
Ukr. J. of Educ. Stud. and Inf. Technol. 2020, 8(4) 


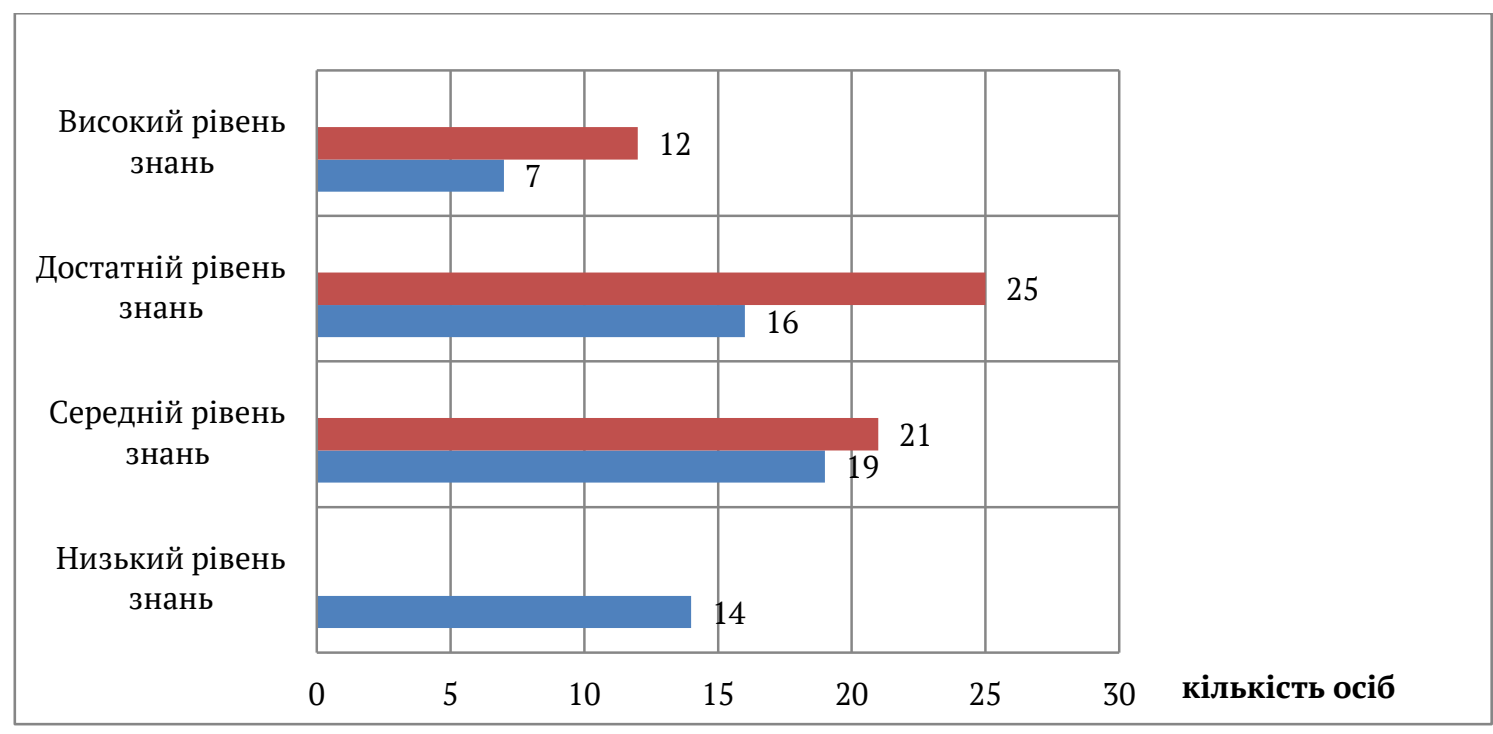

Ukr. J. of Educ.

Stud. and Inf.

Technol.

2020, 8(4)

Рис. 4. Розподіл школярів за рівнем знань 3 фінансової грамотності (відповідь на питання 1 анкети виділено червоним кольором; відповідь на питання 2 виділено синім кольором)

Опрацювання відповідей учнів на четверте запитання анкети засвідчило, що 53 (91,38\%) школярі вважають свої знання з фінансової грамотності такими, які сприяють відчувати себе більш комфортно серед однокласників, в котрих знань 3 цієї проблематики недостатньо. Однак ще залишилася частина школярів, а це 5 (8,62\%) осіб, котрі не відчувають різниці в отриманих особистісних знаннях 3 фінансової грамотності у порівнянні із знаннями 3 окресленого кола питань, які $є$ в інших однокласників.

Участь у п'ятому запитанні анкетного дослідження брали ті школярі, котрі ствердно відповіли «Так» на четверте запитання (це була необхідна умова для подальшої відповіді на наступне запитання анкети (п'яте питання анкети)). Опрацьовані результати вказують: тільки 6 (11,32\%) учнів із 53 використовують знання 3 фінансової грамотності для результативного щоденного управління особистими фінансами. Під час бесіди з учнями, які увійшли в цю групу, нами було відмічено, що усі вони добре подумують й успішно визначають пріоритетність необхідних покупок, особливо при розподілі грошей на витрати, які включають купівлю солодощів, розваги з друзями в кіно та кафе, витрати на транспорт, Інтернет тощо; вміють заощаджувати та знають шляхи накопичення власних коштів; добре ознайомлені з видами фінансового шахрайства; здатні поділитися 3 однолітками знаннями 3 фінансової грамотності.

\section{ВИСНОВКИ ТА ПЕРСПЕКТИВИ ПОДАЛЬШИХ ДОСЛІДЖЕНЬ}

Підсумовуючи вищенаведене висновуємо, що викладання фінансової грамотності у закладах загальної середньої освіти повинно орієнтуватися 
на інноваційний спосіб організації навчання, спрямований на оптимальну побудову інтерактивного та практико-зорієнтованого освітнього процесу й реалізацію його завдань. У процесі використання ігрових навчальних технологій піддаються саморозвитку спеціальні професійно значущі якості учнів та ефективно відбувається підготовка до реалій дорослого життя. Для формування фінансової грамотності серед школярів в закладах освіти важливим слугує механізм варіативності, що забезпечує впровадження в освітній процес ігрового моделювання, в результаті чого відбувається трансформація ціннісних відносин, розвиток творчих здібностей, переорієнтація набутих знань і вмінь із зовнішньої сфери у внутрішню із наступним їх результативним вивільненням.

Проведене дослідження дало змогу констатувати та узагальнити, що саме ігровий компонент навчання $є$ органічним і суттєвим доповненням до «класичних» методів викладання фінансової грамотності у закладах загальної середньої освіти. Використання настільних фінансових ігор оптимізує та вдосконалює освітній процес, так як вони сприяють активізації мислення, закріпленню отриманих знань і вмінь учнів, досягненню позитивних результатів в освітній діяльності учнів, здійсненню оперативного зворотного зв'язку вчителем тощо. Це забезпечує поєднання інтелектуальної та пізнавальної діяльностей, розвиток фінансових компетентностей в учнів, підвищує їхню мотивацію та сповна формує фінансово-освічене молоде покоління.

\section{СПИСОК ВИКОРИСТАНИХ ДЖЕРЕЛ}

Бабире, О. В. (2017). Гейміфікація як інструмент переконання у контексті екологічної культури. Мовні і концептуальні картини світу, (59), 21-26.

Булавенко, С.Д. (2018). Дидактичні основи формування фінансової грамотності учнів. Вісник Чернігівського національного педагогічного університету. Серія: Педагогічні науки, (150), 18-20.

Горбатюк, Р. М. \& Дудка, У. Т. (2019). Підготовка майбутніх фахівців економічних спеціальностей засобами онлайн-сервісу LearningApps. Ukrainian Journal of Educational Studies and Information Technology, 7(3), 42-56. http://doi.org/10.32919/uesit.2019.03.05.

Гранчак, Т. Ю. (2019). Ігрові технології як інноваційний інструмент формування бібліотечно-інформаційного середовища управління знаннями. Наука та інновації, 2(15), 9-10. http://doi.org/10.15407/scin15.02.091.

Зеленська, О. П. (2016). Дидактичні ігри в процесі навчання загальноосвітніх дисциплін майбутніх бакалаврів-правознавців та бакалаврів правоохоронної сфери. Педагогічний альманах, (31), 42-47.

Кізима, Т., Круп’як, І., \& Коломийчук, Н. (2020). Методика викладання фінансової грамотності у вищій школі: досвід та перспективи. Світ фінансів, 3(64), 8-18. http://doi.org/10.35774/sf2020.03.008.

Кізима, Т. О., Ребуха, Л. 3., Письменний, В. В., Коваль, С. Л. та ін. (2020). Методика викладання фінансової грамотності : навчальний посібник. Тернопіль: Економічна думка.
Ukr. J. of Educ. Stud. and Inf. Technol. $2020,8(4)$ 
Ковальчук, В. I. (2017). Методичні рекомендації щодо застосування ігрових технологій в процесі викладання дисциплін соціально-гуманітарного циилу. Київ: Видавничоредакційний відділ НУБіП України.

Кравець, Н. С. (2017). Етапи створення гейміфікованої системи для використання в навчальному процесі ВНЗ. Вісник Харківської державної академії культури. Серія: Соціальні комунікації, (50), 198-206.

Кремень, В. Г. (2002). Філософія освіти ХХІ століття. Освіта України, (103), 6-7.

Курик, М. (2016). Формування пізнавальної активності школярів через сюжетно-рольові та дидактичні ігри. Гірська школа Українських Kарпат, (14), 240-242.

Ukr. J. of Educ.

Stud. and Inf.

Technol.

2020, 8(4)

Лященко, Т. О., Гришуніна, М. В., \& Пічкур, В. Р. (2018). Гейміфікація як одна 3 інноваційних форм навчального процесу. Управління розвитком складних систем, (35), 113-123.

Маркеева, А. (2017). Геймификация как инструмент управления персоналом современной организации. Банковский менеджмент: интеллектуальные активы вамего банка, (5), 5-55.

Мельничук, І. М. (2011). Теорія і методика професійної підготовки майбутніх соціальних працівників засобами інтерактивних технологій у вищих навчальних закладах. (Дис. д-ра пед. наук). ТНПУ ім. Володимира Гнатюка, Тернопіль.

Мельничук, I. М., Ребуха, Л. 3., \& Мельничук, С. Ю. (2008). Формування ціннісних орієнтацій студентів в умовах інтерактивної взаємодії. Мандрівець, 4(75), 55-59.

Письменний, В. \& Коженівський, С. (2020). Енциклопедія для фінансово грамотних школярів. Тернопіль: ФОП Осадца Ю. В.

Приходько, Б. (2014). Стратегічні напрями підвищення рівня фінансової грамотності населення України. Вісник Національного банку України, 2(216), 11-16.

Ребуха, Л. 3. (2017). Инновационные технологии в профессиональной подготовке будущих социальных работников. Теория и методика профессионального образования, $4(1), 112-117$.

Смовженко, Т. С. \& Кузнєцова, А. Я. (2013). Впровадження фінансової грамотності в Україні: сучасний стан і перспективи. Вісник НБУ, (9), 8-16.

Черкашина, Т. Т. \& Аббасова, А. А. (2014). Внедрение игровых технологий обучения как инновационный поиск актуализации профессиональной диалогической компетентности студентов. Весник РУДН, (4), 127-132.

Чечетова, Н. Ф. \& Чечетова-Терашвілі, Т. М. (2019). Фінансова грамотність як запорука успіху управління особистими фінансами. World Science, 2(10(50), 14-20. http://doi.org/10.31435/rsglobal_ws/31102019/6725.

Шапиева, А. С. \& Магомедова, П. К. (2015). Применение игровых технологий в процессе обучения. Евразийский союз ученых, (10), 70-72.

USAID. (2017). Фінансова грамотність, обізнаність та інклюзія в Україні: звіт про дослідження. Додатковий проект IP-FSS в Україні. Проект регіонального економічного розвитку. Взято 3 https://old.bank.gov.ua/doccatalog/document?id=83136332.

Safa, M. A. \& Beheshti, S. (2018). Interactionist and Interventionist Group Dynamic Assessment (GDA) and EFL Learners' Listening Comprehension Development. Iranian Journal of Language Teaching Research, 6(3), 37-56. Retrieved from http://ijltr.urmia.ac.ir/article_120600_7a028bbb2ca75a31452b853d337b9fab.pdf.

Xhemajli, A. (2016). The Role of the Teacher in Interactive Teaching. International Journal of Cognitive Research in Science, Engineering and Education, 4(1), 31-37. http://doi.org/10.5937/IJCRSEE1601031X. 


\section{REFERENCES}

Babyre, O. V. (2017). Gamification as an instrument of persuasion in the context of environmental culture. Movni i kontseptualni kartyny svitu, (59), 21-26. (in Ukrainian)

Bulavenko, S. D. (2018). Didactic bases of pupils' financial literacy formation. Visnyk Chernihivskoho natsionalnoho pedahohichnoho universytetu. Seriia: Pedahohichni nauky, (150), 18-20. (in Ukrainian)

Gorbatuc, R. \& Dudka, U. (2019). Training of future specialists in economics with the help of online service LearningApps. Ukrainian Journal of Educational Studies and Information Technology, 7(3), 42-56. https://doi.org/10.32919/uesit.2019.03.05. (in Ukrainian)

Hranchak, T. Yu. (2019). Games technology as innovative tool for forming a library and information environment of knowledge management. Nauka ta innovatsii, 2(15), 9-10. http://doi.org/10.15407/scin15.02.091. (in Ukrainian)

Zelenska, O. P. (2016). Didactic games in the process of teaching general disciplines of future bachelors of law and bachelors of law enforcement. Pedahohichnyi almanakh, (31), 42-47. (in Ukrainian)

Kizyma, T., Krupiak, I., \& Kolomyychuk, N. (2020). Methods of teaching financial literacy in higher education: experience and prospects. World of finance, 3(64), 8-18. http://doi.org/10.35774/sf2020.03.008. (in Ukrainian)

Kizyma, T. O., Rebukha, L. Z., Pysmennyi, V. V., Koval, S. L. et al. (2020). Financial literacy teaching methodology : a textbook. Ternopil: Ekonomichna dumka. (in Ukrainian)

Kovalchuk, V. I. (2017). Methodical recommendations for the use of game technologies in the teaching of disciplines of the socio-humanitarian cycle. Kyiv: Vydavnycho-redaktsiinyi viddil NUBiP Ukrainy. (in Ukrainian)

Kravets, N. S. (2017). Stages of creating a gamified system for use in the educational process of higher education. Visnyk Kharkivskoi derzhavnoi akademii kultury. Seriia: Sotsialni komunikatsii, (50), 198-206. (in Ukrainian)

Kremen, V. H. (2002). Philosophy of education of the XXI century. Osvita Ukrainy, (103), 6-7. (in Ukrainian)

Kuryk, M. (2016). Formation of cognitive activity of schoolchildren through plot-role and didactic games. Hirska shkola Ukrainskykh Karpat, (14), 240-242. (in Ukrainian)

Liashchenko, T. O., Hryshunina, M. V., \& Pichkur, V.R. (2018). Gamification as one of the innovative forms of educational process. Upravlinnia rozvytkom skladnykh system, (35), 113123. (in Ukrainian)

Markeeva, A. (2017). Gamification as an instrument for managing personnel in a modern organization. Bankovskij menedzhment: intellektualnye aktivy vasheho banka, (5), 5-55. (in Russian)

Melnychuk, I. M. (2011). Theory and Methodology of Professional Training of Future Social Workers by Means of Interactive Technologies in Higher Educational Institutions. (Doctor's thesis). TNPU im. Volodymyra Hnatiuka, Ternopil. (in Ukrainia)

Melnychuk, I. M., Rebukha, L. Z., \& Melnychuk, S. Yu. (2008). The formation of students' value orientations in the conditions of interactive communication. Mandrivets, 4 (75), 55-59. (in Ukrainian)

Pysmennyi, V. \& Kozhenivskyi, S. (2020). Encyclopedia for the financially literate schoolchildren. Ternopil: FOP Osadtsa Yu. V. (in Ukrainian)

Prykhodko, B. (2014). The strategic direction of raising the level of financial literacy Ukraine. Visnyk Natsionalnoho banku Ukrainy, 2(216), 11-16. (in Ukrainian)

Rebukha, L.Z. (2017). Innovative technologies in the professional training of future social workers. Teoriya i metodika professionalnogo obrazovaniya, 4(1), 112-117. (in Russian) 
Smovzhenko, T. S. \& Kuznietsova, A. Ya. (2013). Financial literacy introduction in Ukraine: current state and prospects. Visnyk NBU, (9), 8-16. (in Ukrainian)

Cherkashyna, T. T. \& Abbasova, A. A. (2014). Implementation of game learning technologies as an innovative search for actualization of students' professional dialogical competence. Vesnyk RUDN, (4), 127-132. (in Russian)

Ukr. J. of Educ.

Stud. and Inf.

Technol.

2020, 8(4)

Chechetova, N. F. \& Chechetova-Terashvili, T. M. (2019). Financial literacy as a key to the success of personal finance management. World Science, 2(10(50), 14-20. http://doi.org/10.31435/rsglobal_ws/31102019/6725. (in Ukrainian)

Shapieva, A. S. \& Mahomedova, P. K. (2015). Application of game technologies in the learning process. Evrazijskij soyuz uchenyh, (10), 70-72. (in Russian)

USAID. (2017). Financial literacy, awareness and inclusion in Ukraine: a research report. Additional IP-FSS project in Ukraine. Regional Economic Development Project. Retrieved from https://old.bank.gov.ua/doccatalog/document?id=83136332. (in Ukrainian)

Safa, M. A. \& Beheshti, S. (2018). Interactionist and Interventionist Group Dynamic Assessment (GDA) and EFL Learners' Listening Comprehension Development. Iranian Journal of Language Teaching Research, 6(3), 37-56. Retrieved from http://ijltr.urmia.ac.ir/article_120600_7a028bbb2ca75a31452b8533d337b9fab.pdf.

Xhemajli, A. (2016). The Role of the Teacher in Interactive Teaching. International Journal of Cognitive Research in Science, Engineering and Education, 4(1), 31-37. http://doi.org/10.5937/IJCRSEE1601031X.

\section{Про авторів:}

Ребуха Лілія Зіновіївна, кафедра освітології і педагогіки, Західноукраїнський національний університет, Тернопіль, Україна. ORCID: https://orcid.org/0000-00020054-0651.1_rebukha@ukr.net

Кізима Тетяна Олексіївна, кафедра фінансів ім. С.І.рія, Західноукраїнський національний університет, Тернопіль, Україна. ORCID: https://orcid.org/0000-00029732-9907. tetyana.kizyma68@gmail.com

Письменний Віталій Валерійович, кафедра фінансів ім. С. І. Юрія, Західноукраїнський національний університет, Тернопіль, Україна. ORCID: https://orcid.org/0000-00017852-3627.pysmennyi@i.ua

About the authors:

Liliia Z. Rebukha, Department of Educology and Pedagogy, West Ukrainian National University, Ternopil, Ukraine. ORCID: https://orcid.org/0000-0002-0054-0651. 1_rebukha@ukr.net

Tetyana O. Kizyma, Department of Finance named after S. I. Yuriy, West Ukrainian National University, Ternopil, Ukraine. ORCID: https://orcid.org/0000-0002-9732-9907. tetyana.kizyma68@gmail.com

Vitalii V. Pysmennyi, Department of Finance named after S. I. Yuriy, West Ukrainian National University, Ternopil, Ukraine. ORCID: https://orcid.org/0000-0001-7852-3627. pysmennyi@i.ua 